\title{
SOCIOPSYCHODRAMA: Protagonist-centered sociopsychodrama
}

\section{SOCIOPSICODRAMA: Direção centrada na protagonização SOCIOPSICODRAMA: Dirección centrada en la protagonización}

\author{
Luís Falivene Alves ${ }^{1, \star}$
}

Falivene Alves, L. (D) https://orcid.org/0000-0002-5213-5201

\begin{abstract}
Sociopsychodrama, as a group intervention method, enables directing strategies referenced to different approaches that prioritize protagonization, sociometry, or the spontaneous theater, among other probabletheories. This article will highlight protagonist-centered sociopsychodrama, illustrated by a session held at the XV Brazilian Psychodrama Conference's opening. It will also address the protagonist's concepts, protagonic theme, protagonic agent, the description of the several phases and their processing, and the identification of the protagonist of the sociopsychodrama held. Keywords: Sociodrama; Psychodrama; Directing strategies; Protagonist.
\end{abstract}

RESUMO: O sociopsicodrama, como método de intervenção grupal, possibilita estratégias de direção referenciadas a diferentes focos que priorizam a protagonização ou a sociometria ou o teatro espontâneo, entre outros possíveis embasamentos. Neste trabalho a ênfase será na direção centrada na protagonização e como exemplo será usado um sociodrama realizado na abertura do XV Congresso Brasileiro de Psicodrama. Serão abordados os conceitos de protagonista, tema protagônico, agentes protagônicos, a descrição das várias etapas e o devido processamento do sociodrama com a identificação do protagonista do sociopsicodrama realizado.

Palavras-chave: Sociopsicodrama; Psicosociodrama; Estratégias de direção; Protagonização.

RESUMEN: Sociopsicodrama, como método de intervención grupal, permite estrategias de gestión referidas a diferentes focos que priorizan la protagonización o sociometría o teatro espontáneo, entre otras posibles fundaciones. En este trabajo se hará hincapié en la dirección centrada en el protagonización y como ejemplo se utilizará un sociodrama celebrado en la inauguración del XV Congreso Brasileño de Psicodrama. Se abordarán los conceptos de protagonista, tema protagónico, agentes protagonistas, la descripción de las distintas etapas y el correcto procesamiento del sociodrama con la identificación del protagonista del sociopsicodrama realizado.

Palabras-clave: Sociopsicodrama; Psicosociodrama; Estrategias de conducción; Protagonización.

1. Instituto de Psicodrama e Psicoterapia de Grupo de Campinas - Campinas, SP, Brazil.

*Corresponding author: falivenealves@uol.com.br

Received: 04 May 2020 - Accepted: 17 Aug 2020

Section Editor: Michael Wieser

This text is an enlargement of chapter's book: Falivene Alves, L. (2008).Estratégias de direção grupal e identificação do agente protagônico nos grupos socioeducativos. In M. M. Marra; H. J. Fleury.(org.) Grupos: intervenção socioeducativa e método sociopsicodramático (p.69-91). São Paulo: Agora 


\section{SOCIOPSYCHODRAMA}

Sociopsychodrama, also referred to as Psychosociodrama, is one of the effective group intervention methods. It is presented in various possibilities, such as qualitative research, role-playing pedagogy, sociometric and sociodynamics change facilitator, and spontaneity-creativity releaser. It is also an efficient instrument for the treatment of conflicts and suffering. Sociopsychodrama is mostly applied in socio-educational groups, comprised of people who, by some criterion, have developed connections among themselves in varied relational configurations and presented different demands. Such demands may be at the level of knowledge, conflict management, clarifications and transformations in their relational structure and will benefit the group and its members individually.

When we do group work, even if the questions brought out concern the group as a whole, we must not neglect the motivations or repercussions at the heart of each member. The same can be seen in those situations where the priority falls upon an individual's needs when the concern will then be to promote the extension or resonance of the work to the entire group present. Therefore, there is no radical distinction between Sociodrama and Psychodrama, since the experience is of a group and not only of the group or within the group. Furthermore, if we always prioritize the relationship, we are compelled to combine this designation as psychosociodrama or sociopsychodrama. (Falivene Alves, 2006a, emphasis in original)

In the sociopsychodramatic work, directing strategies may refer to different approaches. According to each director's preference and experience, he/she may conduct the work prioritizing sociometry, protagonization, improvisational theater, etc. Often, the choice of one of these alternatives happens in the act itself, and it depends on the director's perception of whether the proposal suggested will be welcomed by the group. Here, addressing protagonist-centered sociopsycchodrama, but it must be clear that one can never fail to consider the sociometry present within the group and the dramatic contexts. We will always observe the relationships established between the audience members, the members of the functional unit, the functional unit and the audience, between the characters in the staged scenes and between the characters, the functional unit, and the audience. All these relational bonds build the group's co-conscious and co-unconscious states, which are the basis for protagonization. The various characters that will repeat, produce, or transform plots and conflicts will arise from these instances. The improvisational theater will always serve as background for the whole dramatization. The protagonist-centered sociopsychodrama should allow the protagonic movement to take place, covering the various pre-protagonists who show up, developing a theme that makes sense, and supports the definition of a protagonist: questioner, transformer, integrator, and creator.

\section{PROTAGONIST-CENTERED SOCIOPSYCHODRAMA}

Protagonic theme and protagonist constitute what we can call protagonization. The protagonic theme is the text, the script, or the subject built up and developed during the sociopsychodramatic dramatization. The protagonist is the theme's most significant focus since it is responsible for its unfolding and outcome. "The protagonist theme has its grounding in the social context, it is outlined in the group context, and it is unfolded in the dramatic context". I recall my definition of the protagonist: "the element of the dramatic context that arises through the role-play of a character; this character questions its actions and 
feelings and is an emotional representative for the relationships established between the members of the group,...", and also, ..." the main fighter, the one who will confront the old and the new, the past and the present, the sacred and the profane, the myth and the city..." (Falivene Alves, 1999, 2006b).

When building up the sociopsychodramatic dramatization, we rely on the presence of protagonic agents that comprise all the elements that significantly influence the development of protagonization: 1- the director, who establishes group connection through constant warm-ups; introduces a previously defined theme or searches for issues arising from the group; proposes and concludes scenes; uses techniques and directs the dramatization. 2- the public, also the audience is an important indicator of the protagonic movement, it allows the formation of the co-conscious and co-unconscious states, provides stories, actors, authors; chooses, approves, disapproves, and is overwhelmed by the dramatization, 3- the auxiliary egos who, as antagonists, welcome or complement, help out, provoke, or instigate, making room for the protagonic characters to come up. 4- pre-protagonists or intermediary protagonists are those characters who stand out in several scenes that precede the main dramatization and are important to conduct the protagonic movement towards its apex. 5- the protagonist, the main character, is the outcome of the group's co-conscious and co-unconscious states, the deciphering and transforming agent of the staged drama.

When starting a sociopsychodramatic work, we must be attentive to facts, comments, emotions, and motivations, which precede the event. The reasons for the dramatization must be clear to the functional unit and the audience present. Such reasons may be integration, conflict resolution, research, sociometric and sociodynamics readings, exploring, reflecting, and understanding some themes.

It is also necessary that the people present to identify themselves. Do they know each other? Do they belong to just one predetermined group or different subgroups? Should they introduce themselves first as individuals, or can they already be recognized as a group? Even if we are before a preexisting group, we should use techniques that aim at establishing group connections, incorporating now the functional unit (the director and the auxiliary egos) forming a new group, at that moment, for that activity. The director leads the group intending to establish ways of communicating and interacting in order to build up a sociometric field as a platform to bring out emotional, affective, psychological, and social flows.

The next step is to instruct the group on the proposal already made. There is a warm-up to evoke stories, themes, scenes, and/or feelings- some directors even allow all these possibilities. When there is a small group, we can let them talk freely, stimulating all members to participate until they find a subject of common interest. That is what usually happens in procedural and institutional groups. In medium and large groups, we can also encourage those who seem ready to express themselves. However, dividing the audience into subgroups according to a criterion defined by the director is the most common procedure. With greater proximity and talking among themselves, each subgroup will work on its demands and suggestions and then express them through a story, an image or a scene. The purpose is to find a representation of this group context, allowing the actions to take place within the dramatic context. The individuals or themes selected in the group context are called group representatives.

I would like to take this opportunity to recall the various possibilities to define this group representation: when, still at the beginning of a sociopsychodramatic act or session, we can establish group connection and to state that we are moving from the social context to the group context. Some of the following possibilities take place in the group context: when through the various accounts, complaints, feelings and stories brought out, the group assumes a sociometric configuration around just one element and, through identity mechanisms, let the issues of the other members converge into it, we are then in the face of a group emergent representative. At other times, it is one of the group members who introduces himself/herself in extreme need of help for being in a situation of crisis, either very anxious or depressed and depending on the existence of good group cohesion, there 
may be an intention to help that suffering element. In a spirit of solidarity, the group shows its willingness to care for that element as a priority. In this case, we call it a designated group representative. There are also those situations in which several issues are brought out, and the group does not focus on one theme or another, requiring the use of a strategy that allows the selection of the situation to be dramatized. Here we have a chosen group representative. This element being emergent, designated, or chosen, is not called a protagonist - we are still within the group context, and the protagonist's identification only happens in the development of the dramatic context.

In short: in the group context, depending on the proposed warm-up, several people can express themselves by bringing out their needs, complaints, conflicts, situations, stories, and themes. They are group expressers (manifestantes grupais) and one or more of them will distinguish themselves as possible group representatives. Their best characterization and prominence will take place through three possibilities:

1. Standing out as an emergent, demanding more attention from the group and the director, converging identifications, revealing underlying or even hidden contents.

2. Being designated for evoking affective solidarity or curiosity or for presenting emotional urgency.

3. Being chosen among several manifestations of themes presented.

In any of these possibilities, the highlighted element will be characterized as a group representative.

Once one decides if the work is carried out with one or more contributions brought out, with one or more group representatives, the person or the subgroups selected are invited to enter the space defined as a psychodramatic stage. These group representatives are protagonic agents, authors, and actors who will become characters in the plot that will be unfolded there.

I always work with the idea that, in the dramatic context, the individuals who will be on stage are characters, keeping a certain distance from their roles and situations in the real world, enabling the experience to take place in the "as if". These characters will be messengers from the group co-conscious and co-unconscious states, which are essential for every sociopsychodramatic session. Our view does not prioritize the individual coming from the social context, but the one constructed by the interaction that happens on stage, in the audience, and between stage and audience. In this process, several characters will be created and among them, one will stand out for his questioning, his feelings, and for his mobilizing the collective drama more intensely, which asks for a transformation. This character, the main one, will be announced as the protagonist. Most of the time, it is defined in the last scene.

As a director, I compare myself to a boat helmsman catching a favorable wind to direct the protagonic movement. We can make a stop in a scene for a shorter or longer time, depending on what it will provide us with as if it were a stop made by a vessel for supplies or directions. Continuing with the metaphor, if our purpose focuses on the sociodramatic context, we should not accept an invitation to visit the privacy of one of the travelers' home. By emphasizing the characters' aspects, we would be closer to the psychodramatic field, deviating from sociodramatic purposes. On the other hand, if the emphasis is on the psychodramatic context, we will be extremely curious to know every corner of that home. In a sociodrama act, the questions addressed to the characters should privilege the "what for" of the staged scene; however, in a psychodrama act, the focus is on the "why" of the staged scene.

Each director has his/her directing strategies. From a selected story, scene, or image, one can decide on his/her dramatization style, either through a single scene or through sequential, unfolded or multiplied scenes. Another possibility widely used is to 
consider three or four issues brought out by the audience and act them out in short scenes. If the focus is on protagonization, we should pay close attention to the protagonic theme's development. It is always good to remember that the protagonic theme is outlined in the social context and, therefore, it takes into consideration the "small talk" we hear in the waiting room of an office or the hall of a theater, the subjects of newspapers and radio headlines, economic, political and social issues that are part of that moment etc. Even when we direct a theme sociodrama, the instruction given will just be used as a starter, changing its course. All of this will influence the construction of the co-conscious and the co-unconscious states of the assembled group. Best planned in a group context, the protagonic theme enters the dramatic context and structures itself through its various scenes conducted by several intermediary protagonists. It all happens just like in a track and field event called relay in which athletes run a pre-set distance carrying a baton before passing it onto the next runner until the different distances are covered. We just will not know in advance how many athletes will be needed and how long the racecourse will be. In the initial scenes, the preprotagonic characters and the changes that occur start preparing the field for the emergence of the protagonist, questioner, and transformer. It may happen that one of the initial scenes already brings a heavy protagonic load, making room for the protagonist and the integrating catharsis to emerge right there. In this case, the other scenes previously chosen will no longer be necessary. If, in order not to break the contract, we choose to continue with the dramatizations, they will either have a merely demonstrative nature or will be used during the sharing.

As we have seen, the protagonist-centered sociopsychodrama has as its baseline principle the protagonic theme, developed with the protagonic agents' contributions, and more explicitly by the pre-protagonists and the final protagonist. This will often only be defined in the last scene. At the end of the dramatization, I like to find a name for that sociopsychodramatic act similar to titles we give movies or theater plays. This will help us identify the protagonic theme that unfolded there.

The final sharing can be done by using comments made by the audience, images, brief scenes, silence aiming at internalizing the experience, a round of applause, or any other form of expression that reveals a collective resonance and gratitude.

To conclude and reaffirm, even when the director's focus is on protagonization, we will not fail to appreciate the sociometric aspects present within the group and the dramatic contexts and those of the improvisational creativity theater. Likewise, all the sociopsychodramatic work based on other different theories will always identify a protagonic theme or a protagonist.

\section{A SOCIOPSYCHODRAMA AS AN EXAMPLE}

I choose to illustrate and exemplify the sociopsychodrama act held as the XV Brazilian Psychodrama Conference's opening session in 2006 (Falivene Alves, 2008). Participants of a conference meeting constitute a possible group with the characteristics previously mentioned: subgroups, people still on their own, multiple roles, institutional policy, diverse interests, to make or to meet friends and colleagues, to share and to exchange experiences, to expose, to learn, to teach, etc.

The XV Brazilian Psychodrama Conference took place in São Paulo's city, in November 2006 entitled Percurso e perspectivas do psicodrama no Brasil. Febrap 30 anos I was invited to direct the opening sociodrama session, the first of this event's scientific activities. As I always do, I need to establish a connection with the event itself and contextualize it. What is the purpose of it? Who is my audience? What is the event venue like? What will precede the session? Also, what will happen next? Based on that, some directing strategies are planned. I use my imagination and guess what might happen, to a certain extent, so that the proposal does not become a natural threat when things are unpredictable. I do not think about the scenes that are likely to happen or their probable unfolding since that might trap me in wishing they would happen and hinder my spontaneity. 
A conference is a scientific, social, and tourist event, sometimes also cultural. The registered participants would range from sociopsychodramatists who graduated throughout the thirty years of Febrap's existence to current university students and other curious people interested in learning about psychodrama. We would then have individuals arriving at the conference venue coming from various places and with variable demands. These premises triggered reflections and ideas: I tried to remember other conferences, the institution's growth, our practice, our theory, our progress - a journey through time. The idea had come up: to transform that auditorium into a "big station" for passengers. Some arrive, others leave, a place to come and go where some people wait for something or someone.

The next phase was to share the invitation with the Instituto de Psicodrama e Psicoterapia de Grupo de Campinas (IPPGC) faculty members and invite them to form a functional unit. I would be the director and they would be the auxiliary egos.

We started with an audience of more than three hundred people. I started by reminding them that we were celebrating the 30th anniversary of Febrap, founded in 1976. I mentioned some remarkable political facts which took place in that particular year in Brazil: the deaths of former presidents Juscelino Kubitschek and João Goulart, the Falcão Law limited television and radio campaigning during the two months before the elections for candidates running for city council and mayor, showing only the photo of the candidate, his name, party, and the position for which he was running, federal and state deputies had their political rights revoked. In the world: Mao Tse-Tung's death, the police arrested Isabelita Perón and a military dictatorship was established in Argentina, Mario Soares became the first constitutionally elected prime minister in Portugal. I continued with important cultural facts about movies, soap operas, and songs: Chico Buarque's spectacular success with "Gota d'água", "Olhos nos olhos", "O que será que será?" Some people chanted other songs from that time. I recalled the song "Como nossos pais" by Antonio Carlos Belchior enshrined by Elis Regina and there was a joyous exclamation from the audience. I asked someone to sing a part of the song, which was done as if it were a chorus of several participants. One of the people stood out for knowing the full lyrics and for having a pleasant voice. Tears came out of some people's eyes. A group of latecomers was allowed to enter the auditorium. Next, they were given some time to settle down.

Now the auditorium was quite full, with a five hundred seating capacity. Many participants had already met each other at the cocktail party offered the day before, so I asked them to wave to the ones they had not met from their seats. I realized that the music and the chorus had already started to establish a connection among the participants. The group was relaxed and cheerful.

I began the warm-up for the proposal of this sociodrama: I recalled that Febrap was celebrating its 30th anniversary and I instructed that the auditorium, now as surplus reality, turn into a large passenger station where everyone would be going on or arriving from a trip to celebrate thirty years of "something". The 30th class reunion, the 30th wedding anniversary, the 30th birthday, or his or her child's 30th baptism celebration. A joke: "if you are not thirty yet, you can celebrate your mom and dad's dating anniversary". Everyone there would play the role of these characters: travelers celebrating 30 years of "something". The unit egos would also be characters: travel agents who would be taking notes and meeting travelers' demands. Eyes closed... warming up for the character.

There were several personal testimonies made by travelers, more than twenty. I quoted some, all expressing different wishes: 1- to return to La Paz to look back on his/her life 2- to return to a Christmas party in preschool 3- to get a ticket to Tuscany to celebrate a 30-year- dream to spend summer there 4- to travel to outer space, to change his/her life 5- to celebrate 30 years since he/she first came to study in São Paulo and to be back to São Paulo, again, in search of knowledge 6- to return to his/her African American mother's womb to live that Negritude 7 - to return to Três Pontas to be able to attend Milton Nascimento's , Gonzaguinha's and Chico Buarque's concerts 7- to take a gap year again, just to travel 8- to return to Rio Pardo to say something 
to a former fifth grade teacher who scolded her 9- to be celebrating thirty years of friendship with classmates from University of São Paulo 10- to go to his/her youngest daughter's birthday party 11- to go back to when he/she was 16 and lost his/her mother 12- to meet Moreno, give him a hug and thank him for Febrap's 30th anniversary.

We limited the number of personal testimonies due to the time spent and keeping everyone warmed-up. I proposed that we dramatize three of the narrated situations and select those that were most mobilizing. First, the large group selected three of them: to return to Rio Pardo to speak to the teacher - to return to the mother's womb - to return to Três Pontas to attend Milton Nascimento's concert. Upon request, four situations, instead of three, were chosen since the group claimed a tie. The testimony "to return to preschool" was added to the choices.

\section{Dramatizations}

The director assigned the functional unit auxiliary egos complementary roles, and they were free to create. Characters' names were fictitious.

First dramatization- situation 8 Characters: Carol, fifth-grader on her first day of school and English teacher. Setting: the classroom. Proposal: to meet again, to reshape the meeting. Scene: authoritarian teacher scolds the student. Carol is not intimidated. She questions face surprises and exposes a grammar mistake on an agreement in the teacher's speech. The audience laughs and applauds what indicates that the scene, although fast, has already been reparatory and complete.

Second dramatization - situation 7 Characters: a young woman (Maria), her boyfriend, a male friend, and a female friend. Setting: a farm where artists perform: Milton Nascimento, Chico Buarque, Gonzaguinha. The scene unfolds itself with friends being under the influence of alcohol and drugs, the conversation revolving around distorted perceptions, making them not pay attention to the concerts. Director asks how the character would like to end the scene, and she replies: by listening to the song "Amigo", by Milton Nascimento. The auditorium spontaneously sings the song in the chorus and performs choreography with their arms. Maria gets emotional, hugs her friends. The scene ends.

Third dramatization - situation 6 Characters: Pedro and his mother. Director recalls that he wanted to return to the mother's womb, but Pedro replies that it is not necessary that he would like to meet his mother. Setting: undefined. Pedro tells his mother that the distance between them did not make him lose his roots, African American identity and sing a melody to exalt their race.

Fourth dramatization - situation 2 Characters: preschool student (Antônio) and a nativity scene figure. Setting: elementary school auditorium. Scene: it is Christmas; Antônio is on stage before a nativity scene. He has never seen those figures, he wants to get closer, he is kind of afraid. The scene director takes his hand and encourages him. Antônio says he wants to change the figure; he wants to interact with it. He comes closer, changes its body expression, and sits it, as a speaker facing it. He says that instead of a nativity scene, he sees the future there, the 2036 Conference. There are many new people, many of this group's participants have grown old and bald and have grown a belly. As for himself, he says that, in the meantime, he has also aged, gained weight, written a book, had presentations to which no one showed up, received criticisms that made him grow up, felt like giving up, fought and reconciled with Moreno, dropped certain concepts, rescued others. Now, there was no longer a standing figure there, but a living organism. They stand up and hug one another.

Once the dramatizations are over, the director calls all the protagonists on stage and thanks to them for coming up with such necessary "trips". He points at each protagonist: here is Carol, the student who reveals to her teacher that she also knows how to teach; young Maria shows that occasionally, in our lives, we become in-tuned to our inner self, without looking at our outer 
self, and that, in new situations, can be recovered; Pedro, reaffirms his roots, his identity; Antônio joins the nativity scene, the figures, the myths, making them feel more alive, more human. Let us put these four characters together in one. Our sharing will then take place, incorporating this character that will accompany us during these conference days. Let us close our eyes and let that happen. We have elected them, let us welcome them back.

From now on, this will be our character: conference participant, let us give it a name. After several suggestions, "Open to the new" is chosen.

That is the protagonic character: conference participant, the one who has identity, roots, the one who will be able to recover or see again what he/she has missed in other conferences, the one who has something to present and to teach his/her colleagues and teachers, the one who knows how to modify, to integrate himself/herself and be part of an always dynamic nativity scene.

The sociodrama ends with many congratulations given.

\section{Reflections on the protagonist and the protagonic theme - Sharing}

The XV Conference was entitled Percurso e perspectivas do psicodrama no Brasil. Febrap 30 anos. There is a great probability that the idea of time: past, present, and future would function as a guiding reference for the sociopsychodrama theme. The initial warm-up aimed at establishing a connection and having the first conscious contact with the subject. Belchior's song "Como nossos pais" gained more strength and the auditorium turned out to be the singer and the chorus of the song, adding sound to the verses, I highlighted some of them: "...vejo vir vindo no vento o cheiro de uma nova estação ..., é você que ama o passado $e$ que não vê que o novo sempre vem..., ...ainda somos os mesmos e vivemos como nossos pais...." It foreshadowed the proposal for joining the surplus reality: passengers at a station, returning from or leaving for celebrating trips. The number of testimonials from travelers, about twenty, confirmed the progress of protagonization.

The next step was to ask the group to indicate the candidate stories for dramatization. There were five of them, and four were chosen. I called the people chosen group representatives. They were not protagonists yet because we were still within the group context while defining them. Remember that the group representative can be designated, chosen, or emergent.

Once the dramatizations started, the protagonic movement would go through several scenes and several characters. The travelers, initial authors, became characters of the desired scene or the scenes not yet modified and, within this dramatic context, they became protagonists. Carol: she faces her fear; she also knows how to teach. Maria: she can now look outside herself; she can choose what she wants to hear. Pedro: he sees himself being born many other times, without losing his roots.

The last dramatized scene was the peak of this leading movement; all of its precursors were contained in there. This is where the protagonist is most fully defined.

Antônio is happy to be on the school stage, he knows he is doing something important, he comes across the nativity scene, is curious, wants to get closer to it, and is afraid. Teachers, artists, parents, gods are myths that are triggered at the same time: desire and fear of getting closer. In order to achieve his goal, Antônio needs to modify the image. Make it more human, more like him, more symmetrical. The same occurs in the previous scenes. Once the image is demystified, Antônio frees himself for the future, envisions himself overcoming criticism, showing himself, writing, leaving some things behind, rescuing others, joining the temple of myths, the humanized nativity scenes, always dynamic. In this last scene, the conference and its theme reappeared. The

1. I see coming in the wind the smell of a new season..., it is you who loves the past and does not see that the new always comes..., we are still the same and we live as our parents do... (free translation). 
past was present, and it projected itself as the future. Past, present, and future were together in one single moment. Psychodrama presented itself as a path and as a perspective. The protagonist defined itself as the conference participant during the protagonic movement covered.

I am convinced that the transformation that happened in the last scene came due to the changes that had occurred in the previous scenes. Antônio was able to get closer to the nativity scene because Carol had already demystified her teacher. He was able to look to his future because Maria had already seen and heard what came from outside. He could see himself facing doubts and obstacles because Pedro had affirmed his origin, his mother's womb. All of these were protagonists of their scenes and preprotagonists of the final scene. The protagonist of this sociodrama was defined in Antonio's scene. Neither Carol, Maria, nor Pedro, nor Antônio, but the character built by everyone, is evident in the final scene. It came from the co-conscious and the co-unconscious states of the group. Our protagonist is the one who modifies, who teaches, who learns, who fights, who recreates. It is through the protagonist that the conference participant character reappears. It is the conference participant here present, and that is how we will share it. We will not only have the newcomer or the oldest of the psychodramatists represented in the protagonist; everyone there will have traveled the same path, will have recognized their identities, will be given a name to continue - "open to the new".

Our protagonist of the sociodrama act was today's conference participant, a psychodramatist who has a history of more than thirty years and who will follow his/her path for another thirty years. The staged scenes, metaphors of this path, have brought us to facts, phases, and significant institutional biography periods. We saw ourselves in the historic confrontation with the first foreign masters and as a result several federal units were founded. We remember the beginning of the Brazilian psychodramatic movement in the late sixties and early seventies, a time of ideological challenges, changes in customs, the search for alternatives, but also a time of significant military repression. Psychodrama was growing in a euphoric way, however, turned in upon itself, with little action in private offices. We went from self-adoration to self-criticism; many sought other sources of knowledge, other theories. We matured, broadened our theory, revalued and asserted ourselves as socionomists and Morenians. We recorded and defended our origin, our roots. We unveiled and desecrated myths became partners, allies, creating space for equality and difference, teaching and learning, and creating new possibilities. We expanded our field of expertise. We will be in the future.

This whole story was in the co-conscious and co-unconscious states of the group, and through the dramatizations of Carol and her teacher, Maria and her friends and singers, Pedro and his mother, Antônio and the nativity scene, we were able to experience them, update them, and dramatize them.

Retracing the protagonic movement's path in the reported sociopsychodrama, we see that its premise, still within the social context, was enunciated by the conference theme (thirty years of the institution, path and perspective of psychodrama). The director conducts it to the group context through the proper warm-ups, placing the auditorium in 1976, the year the institution was founded. The group chooses one song from that time out of a few suggestions: "Como nossos pais", in which lyrics show the conflict between the new that presents itself and previous recurring patterns. Then the protagonic theme begins to be outlined. The "as if" of a passenger station is proposed, a possibility for several paths. The group nominates its representatives to resolve the psychodramatic stage's impasse: the new or the old. The chosen narratives wish to return - returns that are shown to be necessary for the due releases. One by one, the characters could confront each other, look back on their lives, and assert themselves. The protagonic theme defines itself increasingly within the dramatic context and heads towards its apex. The pre-protagonists now give way to the protagonist, the transformer, who makes the past its origin, no longer its prison. Now it can go, it can feel the wind through a new station, it is heading for the future. One can now sing: "Já não somos os mesmos, nem vivemos como nossos pais"

2. We are not the same anymore, nor do we live like our parents (free translation). 


\section{CONCLUSION}

I call your attention again because the group is not considered a protagonist but a client or subject, target of the proposed work, providing subsidies for protagonization. Whether in psychodrama or sociopsychodrama, the protagonist is an element that appears within the dramatic context and is always experienced through characters. The only possibility of seeing the group as the protagonist will be in situations in which the dramatization focuses on an institution, an association, a family, or a particular group in confrontation with an antagonist. Even in these situations, it will be the group, now as a character, that will be on the psychodramatic stage, having the possibility to distinguish itself as the main fighter and to conduct the protagonic movement.

In sociopsychodrama sessions, we can choose from several models of direction. It is quite common, and more often in the case of medium and large groups, that after the proper warm-up, the audience is divided into subgroups to narrate stories, create scenes or images, and subsequently promote the choice of one of them to be dramatized, in which the protagonist will be defined. Another possibility is to work with four shorter scenes, as reported in the example described. In this case, we must pay attention to developing the protagonic theme that will cover the various scenes and the various intermediary protagonists. As has been said, it all happens just like in a track and field event called relay in which athletes run a pre-set distance carrying a baton before passing it onto the next runner until the different distances are covered.

Whatever the form was chosen for the completion of a sociodrama, our focus should always be on protagonization. Whether we are working with a single scene or with several scenes, with dramatic games or with the various formats of the improvisational theater, the direction of a sociopsychodrama should allow the occurrence of the protagonic movement, covering the various pre-protagonists who present themselves, developing a theme that makes sense and favoring the definition of the protagonist: questioner, transformer, integrator, and creator

The several sociopsychodramatic direction models are the results of psychodrama's creative freedom, which allows each director to find the strategy that best adjusts to one's understanding of group dynamics and interventions one aims to pursue.

In the current social context stricken by the COVID-19 pandemic, we realize that physical distancing, required for the prevention, has accentuated insecurity and shown personal solution failure. It has also exacerbated the need to share feelings and conflicts and find collective solutions, bringing to light the great opportunity and importance of sociopsychodramatic group work. Sociopsychodramatic group work is the future therapy: It goes beyond the individual, taking care of the groups one belongs to.

\section{REFERENCES}

Falivene Alves, L. (1999). O protagonista e o tema protagônico. In W. C. Almeida. (org.). Grupos-a proposta do psicodrama (pp. 89-100). São Paulo: Ágora.

Falivene Alves, L. (2006a). Grupo: Lócus da saúde e da doença do homem. Revista Brasileira de Psicodrama, 14 (1), $131-139$.

Falivene Alves, L. (2006b). The protagonist and protagonic theme. In Z. Figusch. (org.) Sambadrama: The Arena of Brazilian Psychodrama (pp. 130-40). London: Jessica Kingsley.

Falivene Alves, L. (2008). Estratégias de direção grupal e identificação do agente protagônico nos grupos socioeducativos. In M. M. Marra; H. J. Fleury.(org.) Grupos: intervenção socioeducativa e método sociopsicodramático (pp.69-91). São Paulo: Agora

Falivene Alves, L. (2008). A identificação do agente protagônico nos grupos socioeducativos. In M. M. Marra; H. J. Fleury. (org.) Grupos: intervenção socioeducativa e método sociopsicodramático (pp.76-91). São Paulo: Agora. 